\title{
The Impact of Teaching Practice on Trainee Teachers in the Nigerian Tertiary Institutions: The Niger Delta University Experience
}

\author{
Andabai, Priye .W \\ Department of Finance and Accountancy, \\ Niger Delta University, \\ Bayelsa State, Nigeria
}

Doi:10.5901/ajis.2012.v2n5p109

Abstract

This research evaluates the impact of teaching practice on trainee teachers in tertiary institutions in Nigeria: the Niger Delta University Experience. Questionnaire was used to collect the data; one hundred and twenty (120) students (respondents) from the faculty of education were selected using simple random sampling. The result showed that trainee teachers benefited greatly in participating in teaching practice because they were able to build proper confidence and competence in lesson preparation and developed skills and attitude of a teacher during the exercise. It was also revealed that teaching practice helps trainee teachers to learn how to keep records of assignment and also participating in school activities. Therefore we recommend that government should provide finance inform of stipend for trainee teachers and teachers engaged in teaching practice prgoramme. A proper orientation for trainee teachers should be carried out using efficient means of communication like; seminars, workshops, conferences and discussion. Faculties of education and colleges should organize the exercise very well so as to give the best professional practice to the trainee teachers. The university should appeal to non-governmental organizations like the private sector, individuals and industries to assist in supplementing educational materials and learning resource that would prepare the students.

\section{Introduction}

Okorie (1986) stated that, education is a part of life, which is deliberately controlled and experiences developed according to a conscious plan. According to Emereole (2000), it is usually planned according to the individual and societal needs and the most veritable instrument for change in any society. Therefore, the quality of education provided in any society and the nature of the change affected by that education are both dependable on the quality of teachers and the affected by that education are both dependable on the quality of teachers and the effectiveness of their teachings in schools (Awotua-Efebo, 1999). Kizlik (2007) posits that, education is a means to cooperative dynamic and life long process through which a society deliberately generates knowledge, skills, values and other form of behavior for its survival and sustenance, and transmits these from one generation to another. Asuru (2000) observed that, it is pertinent to note that the individual countries of the world provide education for their citizens for different reasons. According to Adagba (2005), the reasons are the different ways, which these countries believe that they would help the citizens as human being and their country as a Nation.

Akpomi (2010) also stressed that, the Government of Nigeria in her aim to achieve their philosophy of education has therefore set up an implementation committee for the National Policy of Education in 1983, knowing fully that, the important of teaching practice and internship in teaching education can not be overemphasize, the committee therefore recommends: i. Those methods of training teachers need to be rationalized, so that they reflect the Nation's, Education philosophy, policies and structure. ii. That massive training of untrained primary school teachers should be done by the method on the job training. iii. The selection and training of lead teacher who will provide personal instruction to teacher, trainee and supervise them well. Mann (1995) stressed that, the impact of teaching practice on trainee teachers in tertiary 
institution has been of interest to researchers, government, teachers and parent as well. Similarly Obagah (2000) defines teaching practice as the performance of the kind of activity that results in learning. Koko (2002) remarked that, teaching practice in most educational institution is the expected terminal behavior of a student teacher who is going through professional course in education.

\section{Conceptual Framework}

Mkpandiok (2006) observed that, for the past 15 years, scholars have embarked on extensive research in other to adopt teaching techniques to tackle the issues of the differences among individual learners with regard to the social and institutional contexts of teaching in higher education. According to Sipek (1988), and in recent time the theories and methods of research on teaching in terms of understanding and how academics experience teaching. In the light of this, the work of Okorie (1986) has been an improvement on earlier studies as well as noting the lack of research on the associated intention or motives of teachers. The authors have investigated the extent to which university teachers conceptualized teaching in different ways (Koko, 2002). Practice teaching occupies a key position in the programmed of teacher education, it is a culminating experience in teacher preparation (Nnamdi, 2000).

Adagba (2005) stressed that, this exercise provides opportunity to beginning teachers to become socialized into the profession. Ajoku (2003) asserted that, performance during practice teaching provide some basis for predicting the future success of the teacher outgoing popularity and centrality of practice teaching is an important contributing factor towards the quality of teacher education programmed. Edem (2003) confirmed that, during practice teaching, working with students in schools provide a high degree of emotional involvement of a mostly positive nature. Students teachers feel themselves grow through experience and they begin to link to a culture of teaching. Murray (2007) asserted that, during practice teaching, they feel engage, challenged and even empowered. Amaewhule (1993) reaffirmed that, practical teaching experience is under taken by students in faculty of education in Universities and Colleges. Imart (2003) reaffirmed that, it is an essential aspect of teacher education because it prepares teachers for their future teaching roles and assignment. The main agents who implement educational policies has to be properly organized and teaching practice also helps in this function (Hyon, 1999).

Osuala (2004) concluded that, teaching practice expose the trainee teacher to the realities of effective teaching and help them to try out methods of teaching and gain practical classroom experience under expect supervision. Wellington (2006) explained that, during the teaching practice, the trainee teachers are sent out from the University and College to primary, secondary, commercial, comprehensive and technical schools to teach for a period of time as a part of their training. According to Andabai (2011), during this practice a student is supervised and evaluated not only by a supervisor allotted to him but also by a group of other lectures who supervises him as a team as well as a staff of the school in which he is teaching. Akpomi (2001) argued that, the need for this different evaluation is to make sure that he is properly corrected and graded. Itejere (1998) stressed that, teaching practice is the most vital part of trainee teacher's career training, this is because it is during this practice that the trainee teachers applies the methods, even the philosophy of education which he was taught theoretically in the classroom. He now realizes this professional responsibility as a teacher and starts to learn how to manage the younger ones who will be left under his control and care.

Edem (2003) also stressed that, teaching practice is a period in teachers in the teacher training institutions and universities are made to under go a period of internship or apprenticeship within the school system. Just like they would be engineers going for industrial training to gain practical experience of what the job is all about, the trainee medical doctor goes through clinical studies and horsemanship. (Ihekwoaba, 2005). According to Haddad (1994), the teachers are exposing to a period of supervised teaching; this is in line with educational theories which associate learning with doing. For a real teacher to emerge, he must acquire the necessary skill from a master craftsman who is usually an educational. According to Emerole 
(2000) teaching practice embraces all the learning experiences of student teachers in schools. Ashraf (1999), the term practice teaching is an experience of guided teaching in which the trainee teacher assumes increased responsibility for directing the learning of a group for over a period of time Imart 2003 confirmed that, also the term practice teaching has three major connotations the practicing of teaching skills and acquisition of the role of a teacher, the whole range of experiences and practical aspects of the course as distinct from theoretical studies practice teaching is the name of the preparation of student teachers for teaching by practical training. Andabai (2011) posits that, it is the practical use of teaching principles, teaching techniques and practical training/practical exercise of different activities of daily school life. Hassan (2000) asserted that, it is a period which provides opportunities under typical school conditions in selected cooperating schools for trainee teachers to secure experience in observing and participating activity in diverse educational activities of teaching in the school.

In March 1987, the American Association of higher education first published "seven principles of good practice in undergraduate education" these seven principles are a meta-analysis of 50 years of research on good teaching principles by Chickenking (1996). Murray (2007) reaffirmed that, they must make what they learn part of themselves, student teacher give assignments to encourage students to apply the concepts learned in the course. iv. good practice gives prompt feedback, knowing what you know and don't know how to focus your learning in getting started, students need help in assessing their existing knowledge and competence then in classes students need frequent opportunities to perform and receive feedback on their performance. At various points during college, and at its end, students need chances to reflect on what they have learned, what they still need to know, and how the might assess themselves. Lew (2009) further stated that, it helps student teacher to know what type of feedback to expect from their student or learners and how often it will be provided. v. good practice emphasizes time on task, time plus energy equals learning, learning to use one's time well is critical for students and professional's alike allocating realistic amounts of time means effective learning for students and effective teaching for faculty. vi. Good practice communicates high expectations; expect more and you will get it. High expectations are important for every one for the poorly prepared for those unwilling to exert themselves, and for bright and well motivated. Expecting students to perform well becomes a self-fulfilling prophecy. vii. Good practice respects diversity talents, experience and ways of learning. Many road lea to learning, different students bring different talents and styles to college, brilliant students in a seminar might be good in practical, students need opportunities to show their talent and learn in ways that work for them. They can be pushed to hear in new ways that do not come so easily (Hassan, 2006).

\section{Methodology}

Data were sourced mainly from the primary sources. The instrument that was used for data collection for the purpose of this study was the questionnaire. The questionnaire is divided into two section, A and B section, section (A) seeks the personal data of the respondent, while section (B) seeks the consent of the respondent. The data collected for the study was analyzed using the simple percentages.

\section{Analysis and Discussion}

This section deals mainly with the representation and analysis of data collected. The analysis is presented in the form of data classification.

Table 1: What are the benefits of teaching practices to trainee teachers? 


\begin{tabular}{|c|c|c|c|c|c|c|c|}
\hline $\mathrm{S} / \mathrm{N}$ & QUESTIONS & SA & A & DA & SD & $\%$ & REMARK \\
\hline 1 & $\begin{array}{l}\text { Teaching practice has made me to decide whether } \\
\text { or not to take to teaching as a profession. }\end{array}$ & 57 & 30 & 16 & 17 & 3.3 & Agree \\
\hline 2 & $\begin{array}{l}\text { Teaching practice developed in me the interest of } \\
\text { working with children of school age. }\end{array}$ & 40 & 60 & 20 & - & 2.5 & Agree \\
\hline 3 & $\begin{array}{l}\text { There is an opportunity of trying out ideas and } \\
\text { theories in a practical classroom situation. }\end{array}$ & 37 & 38 & 18 & 27 & 3.3 & Agree \\
\hline 4 & $\begin{array}{l}\text { One has the opportunity of communicating and } \\
\text { interacting closely and sympathetically with } \\
\text { children of school age. }\end{array}$ & 72 & 48 & - & - & 1.6 & Disagree \\
\hline 5 & $\begin{array}{l}\text { Teaching practice has made trainee teachers to } \\
\text { master professional skills. }\end{array}$ & 80 & 40 & - & - & 1.6 & Disagree \\
\hline 6 & $\begin{array}{l}\text { Teaching practice has made trainee teachers learn } \\
\text { how to plan, prepare and present their lesson } \\
\text { topics. }\end{array}$ & 70 & 30 & 8 & 12 & 3.3 & Agree \\
\hline 7 & $\begin{array}{l}\text { Teaching practice has exposed one to the problems } \\
\text { and prospects of the teaching progression. }\end{array}$ & 50 & 45 & 25 & - & 2.5 & Agree \\
\hline 8 & $\begin{array}{l}\text { Teaching practice helped trainee teachers in } \\
\text { understanding of the principles of child } \\
\text { development and growth. }\end{array}$ & 43 & 50 & 27 & - & 2.5 & Agree \\
\hline 9 & $\begin{array}{l}\text { Teaching practice helped trainee teacher to } \\
\text { broaden their knowledge of the subject matter. }\end{array}$ & 60 & 50 & 10 & - & 2.5 & Agree \\
\hline 10 & $\begin{array}{l}\text { Teaching practice has help one to perfectly use } \\
\text { instructional materials when teaching. }\end{array}$ & 50 & 60 & 10 & - & 2.5 & Agree \\
\hline 11 & $\begin{array}{l}\text { Teaching practice act as a resource centre to the } \\
\text { school. }\end{array}$ & 20 & 30 & 40 & 30 & 3.3 & Agree \\
\hline 12 & $\begin{array}{l}\text { Trainee teachers adequately control their } \\
\text { classroom with assistance. }\end{array}$ & 30 & 40 & 30 & 20 & 3.4 & Agree \\
\hline 13 & $\begin{array}{l}\text { Teaching practice has made trainee teachers to } \\
\text { observe the different features of school curriculum } \\
\text { at work and how each contributes to learning. }\end{array}$ & 60 & 50 & 5 & 5 & 3.3 & Agree \\
\hline 14 & $\begin{array}{l}\text { Teaching practice has help trainee teachers to be } \\
\text { familiar with school records and the complex set of } \\
\text { rules and regulations. }\end{array}$ & 70 & 15 & 10 & 25 & 3.3 & Agree \\
\hline 15 & $\begin{array}{l}\text { Teaching practice has helped one to pass the } \\
\text { teaching requirement to quality as teachers. }\end{array}$ & 30 & 20 & 45 & 25 & 3.3 & Agree \\
\hline 16 & $\begin{array}{l}\text { Teaching practice has helped trainee teachers to } \\
\text { acquire those valuable personality attribute } \\
\text { associated with outstanding teacher. }\end{array}$ & 50 & 35 & 5 & 30 & 3.3 & Agree \\
\hline 17 & $\begin{array}{l}\text { Teaching practice has helped one to gain valuable } \\
\text { insight into him with regard to assessing his } \\
\text { suitability for the teaching profession. }\end{array}$ & 40 & 55 & 9 & 16 & 3.3 & Agree \\
\hline 18 & $\begin{array}{l}\text { Trainee teachers see teaching practice as a vital } \\
\text { factor in preparing student for future teaching } \\
\text { assignment. }\end{array}$ & 45 & 47 & 28 & - & 2.5 & Agree \\
\hline 19 & $\begin{array}{l}\text { Trainee teachers develop their own way of } \\
\text { working effectively with children and colleagues. }\end{array}$ & 46 & 35 & 20 & 19 & 3.3 & Agree \\
\hline 20 & $\begin{array}{l}\text { Teaching practices has made trainee teachers to } \\
\text { gain general experience in academic profession. }\end{array}$ & 28 & 21 & 50 & 21 & 3.3 & Agree \\
\hline
\end{tabular}

Source: Field data (2013). 
From table 2 we can see that, out of 120 responses collected from the respondents, question 1, 2, 3, 6, $7,8,9,10,11,12,13,14,15,16,17,18,19,20$, items where above the cut off point of 2.5 which the respondents agree to the research questions, while questions 4 and 5, disagree to the research questions. Therefore, from this analysis we can conclude that trainee teachers derive great benefit in participating in the teaching practice exercise.

Table 2: What challenges do trainee teachers face in their place of training?

\begin{tabular}{|c|l|c|c|c|c|c|c|}
\hline S/N & QUESTIONS & SA & A & DA & SD & \% & REMARK \\
\hline 1 & $\begin{array}{l}\text { Teaching practice has given trainee teachers the } \\
\text { opportunity to relate their studies to their future } \\
\text { careers. }\end{array}$ & 65 & 55 & - & - & 1.6 & Disagree \\
\hline 2 & Some schools reject trainee teachers. & 11 & 25 & 28 & 56 & 3.3 & Agree \\
\hline 3 & $\begin{array}{l}\text { Permanent teachers are not friendly } \\
\text { In some school teaching staff hoard professional } \\
\text { advice from trainee teachers. }\end{array}$ & 30 & 44 & 16 & 30 & 3.3 & Agree \\
\hline 5 & $\begin{array}{l}\text { Trainee teachers face accommodation problems in } \\
\text { places they are posted to }\end{array}$ & 38 & 42 & 40 & - & 2.5 & Agree \\
\hline 6 & $\begin{array}{l}\text { Some schools lack instructional materials for } \\
\text { effective teaching. }\end{array}$ & 60 & 40 & 8 & 12 & 3.3 & Agree \\
\hline 7 & $\begin{array}{l}\text { Trainee teachers in some cases are not given } \\
\text { subject in their area of study to teach and so could } \\
\text { not perform. }\end{array}$ & 45 & 34 & 3 & 38 & 3.3 & Agree \\
\hline 8 & $\begin{array}{l}\text { Trainee teachers meet some rudely behaved } \\
\text { student. }\end{array}$ & 40 & 50 & 30 & - & 2.5 & Agree \\
\hline 9 & School students do not respect trainee teachers & 52 & 48 & 7 & 13 & 3.3 & Agree \\
\hline 0 & $\begin{array}{l}\text { Trainee teacher lack good professional } \\
\text { relationship between the student and members of } \\
\text { the school staff. }\end{array}$ & 39 & 42 & 39 & 2.5 & Agree \\
\hline
\end{tabular}

Source: Field data (2013).

Table 3 indicates that, question 22, 24, 25, 26, 27, 28, 29, 30, items where above the cut off point of 2.5 which the respondents agree to the research questions, while questions 21 and 23 disagree to the research questions. Therefore, from this analysis it indicates that, trainee teachers face challenges in their place of training.

\section{Conclusion and Recommendations}

Teaching practice has been found to be very beneficial in the course of this research work because, it provides an opportunity for the trainee teachers to teach and increase their professional competence. The result showed that trainee teachers benefited greatly in participating in teaching practice because they were able to build proper confidence and competence in lesson preparation and developed skills and attitude of a teacher during the exercise. It was also revealed that teaching practice helps trainee teachers to learn how to keep records of assignment and also participating in school activities. Therefore we recommended that the government should provide finance inform of stipend for trainee teachers and teachers engaged in teaching practice prgoramme. A proper orientation for trainee teachers should be carried out using efficient means of communication like; seminars, workshops, conferences and discussion. Faculties of education and colleges 
should organize the exercise very will so as to give the best professional practice to the trainee teachers. Institutional resource centers of the various institutions should be adequately equipped and expanded enable every trainee teacher participates at least once or twice in micro-teaching exercise as a way of exposing them to practice teaching. The university should appeal to non-governmental organizations like the private sector, individuals and industries to assist in supplementing educational materials and learning resource that would prepare the students.

\section{References}

Andabai, P. W. (2010). Learning, Organizational Learning and the Learning Organization: Concept, Theories and Models. Journal of Knowledge Management. Vol. 1 No. 2.

Akpomi, M. E. (2001). Organizing Business Education. Port Harcourt Pre Joe Ventures.

Amaewhule, W. (2000). An Introduction to Vocational Education and administration. Owerri: Spring Field Publishers.

Akpomi, M. E. (2001), Organizing Business Education. Port Harcourt: Pre-Joe Publishers.

Asuru, V. A. (2002), Reading in Teaching Practice. Lagos: Minson Nigeria.

Achuonye, K. A. and Ajoku, L.I. (2003). Foundations of Curriculum: Development and Implementation. Port Harcourt. Pearl Publishers.

Adagba, O. and Idu, O. O. (2006). Under Funding: An Impediment to Effective Financial Administration of Higher Institution of Learning in Nigeria. International Journal of Economic and Development. Issues. Vol. 6(2).

Awotua-Efebo E. B. (1999). Effective Teaching: Principles and praCtice. Paragraghics.

Achuonye, K. A. and Ajoku, L.I. (2003). Foundations of curriculum: Development and implementation. Port Harcourt. Pearl Publishers.

Adagba, O. and Idu, O. O. (2006). Under Funding: An Impediment to Effective Financial Administration of Higher Institution of Learning in Nigeria. International Journal of Economic and Development. Issues. Vol. 6(2).

Awotua-Efebo E. B. (1999). Effective Teaching: Principles and Practice. Paragraghics.

Argris, C. and Schon, D. (1978). Organizational Learning: A Theory of Action perspective. Reading, Mass: Addition Wesley.

Baridan, D. M. (1990) Research Methods in Administrative Science. Ibadan: Belk Publisher Nigeria.

Chickenking, (1996), principle of good teaching practice in graduate education. Port Harcourt, Nigeria.

Coats, W. D. (1977). Student perceptions of Teacher: A Factor Analytic Study. Paper Presented the American Educational Research Association Convention, Cited in W. Jones \&

Common, R. (2004). Organizational Learning in a Political Environment: Improving Policy-Making in UK Government. Policy studies, Vol. 25(1).

Erikson, E. H. (1964). Insight and Responsibility. New York: Norton. Retrieved $2^{\text {nd }}$ January.

Eribo, F. (1996). Higher Education in Nigeria: Decades of Development and Decline. A Journal of Opinion, Vol. XXIVII Winter/Spring.

Emereole, H. U. (2000). Problems associated with teaching in Rivers State of Nigeria, A journal of technical and science education.

Edem, D. A. (2003). Introduction to Educational Administration in Nigeria. Onitsha: Leotina Nigeria Ltd.

Federal Republic of Nigeria (2004), National policy on education. Abuja Retrieved (16/02/2010).

Gagne, R. M. The Learning Basis of Teaching Methods. In N.L. Gage (Ed.), Retrieved $2^{\text {nd }}$ January.

Hassan, Bello (2006). Qualitative Technical Teacher Education as a Strategy for Technology Development. International Journal Social and Policy Issues. Vol. 4 (1\&2).

Imart, J. (2003). Two Basic Mechanisms for Organizational Learning in Schools. European Journal of teacher education, Vol. 36, No. 3.

Itejere, P. O. (1998). Teachers Preparation and Professionization of Teaching in Nigeria: The way Forward. A lecture delivered on $13^{\text {th }}$ November on the occasion of NTI Matriculation Ceremony at Baptist High School, Eku.

Ihekwoaba, M. E. (2005). Introduction to Vocational Technical Education. Lagos: Mukugama and Brothers Enterprise.

Jacob A. A, and Herma, J. L. (2009) "Psychoanalysis." Microsoft

Encarta (DVD). Redmond, W. A: Microsoft Corporation.

Koko, M. N. (2000). Foundations of Business Education, Port Harcourt: Pre Joe Publishers. 
Kizlik R. (2007) Classroom Management. Retrieve $20^{\text {th }}$ February,

Koko, M. N. (2001). Teaching Business: method and procedure. Besthand Publishers. Owerri.

Kim, D. C. (1993). The Link between Individual and Organization Learning. Solan Management Review Vol. 38 (16).

Kpeke, E. E. (1992). Is Teaching a profession? In V.F. Peretomode (Ed). Introduction to Teaching profession in Nigeria. Owerri.

Koko M. N. (2002). Organizational Behaviour: Concept and Dimension. Bengray Publishing Company. Port Harcourt.

Kerka, S. (1995). The Learning Organization Myths and Realities. Eric Clear, Lighthouse press.

Lew, W.J.F (2009). Teaching and teacher personality. Retrieve $2^{\text {nd }}$ January.

Lumsden, Linda (2009). Student motivation to learn. ERIC Digest, Number 92. S. Retrieved $2^{\text {nd }}$ January.

Mkpandiok, A. A. (2006). National Policy on Education in the light of the four policy conditions in Nigeria. International Journal of Social and Policy Issues. Vol. 4 (1 \&2).

Nonaka, I. and Takeuchi, H. (1995). The knowledge Creating Company, Oxford University Press.

Nwana, O. C. (1981), introduction to educational research: Ibadan Heineman educational books.

Osuala, E. C. (2004). Foundations of Vocational Education $5^{\text {th }}$ ed. Enugu: Cheston Agency Ltd.

Olashore, O. (1988). Perspectives on Finance, Banking and Economic Policy in Nigeria. Ibadan: Heinermann Educational Books (Nig). Ltd.

Osakwe, E. O. and Okoye, N. S. (1998). The teaching learning process: In Inomiesa, E. A. and Osakwe, E. O. (Ed) principle and Practice of teaching. Warri. Abou Research publishers.

Osuala, E. C. (2004). Principles and Methods of Business and Computer Education. Enugu: Cheston Agency Ltd.

Osuala, E. C. (1996). Foundation of Vocational Education. Nsukka: Falladu Publishing Company.

Obagah (2000), Student application of knowledge of the subject matter. Owerri: Nigeria.

Okorie, J. V. (1986) Fundaments of Teaching Practice: Enugu forth Dimensions Publishes.

Sommers, P. A. (1991) The Delicate Art of Teacher Evaluation. Journal of Experimental Education, 1976, 44, 44-50. Retrieved $2^{\text {nd }}$ January.

Turban, E. and Meredith, J. R. (1994). Fundamentals of Management Science (Sixth Edition). Burr Ridge, III: Richard D. Irwin Inc.

Thompson, R. A. (2009). Child Development. Microsoft ${ }^{\circledR}$ Encarta ${ }^{\circledR}$ (DVD). Redmond, WA: Microsoft Corporation, 2008. 
